\title{
SCIDOC
}

International Journal of Ophthalmology \& Eye Science (IJOES)

ISSN: 2332-290X

\section{Long - Term Results of Primary Pterygium Surgery with Conjunctival Transposition Flap}

Melek Mutlu*, Ayşe Dolar Bilge²

${ }^{1}$ Gaziosmanpaşa Education and Training Hospital, Ophthalmology, İstanbul, Turkey.

${ }^{2}$ Emsey Hospital, Ophthalmology, İstanbul, Turkey.

\section{Abstract}

Purpose: To investigate the long term results of patients underwent primary pterygium surgery with conjunctival transposition flap method.

Material and Methods: Medical records of 27 patients who underwent pterygium surgery by conjuncival transposition flap were reviewed retrospectively. Patients age, gender, mean pterygium size, surgery time, postoperative complications, follow-up time and recurrence rate were evaluated.

Results: Mean pterygium size was $2.8 \mathrm{~mm}$, mean surgery time was 15.9 minutes. Mean follow-up time was 72 months (67-82 months). Only 1 case (\%3.7) of recurrence was observed in our series.

Conclusion: Conjunctival transposition flap technique in primary pterygium surgery is an effective method with low reccurence rate.

Keywords: Pterygium; Conjunctival Transposition Flap; Recurrence.

\section{Introduction}

Pterygium is a fibrovascular tissue originated from conjunctiva and extended to cornea [1]. Depending on the size of the pterygium it can cause ocular discomfort, irregular astigmatisim, visual deterioration and cosmetic concern. The treatment is surgical removal. Bare sclera, primary closure, conjuctival autografting, transpositional flap, amniotic membrane transplantation, combination of antimetabolite usage are the surgical approaches [2-7].

Conjunctival flap techniques, including conjunctival transpositional flap, sliding conjunctival flap, bridging flap and mini-flap, are used in pterygium surgeries since 1940s [8-12]. Easy manipulation of the flap and low reccurence rates are some of the advangates of the flap techniques [13].

In this study we preferred conjunctival transposition flap in cases with primary pterygium and we aimed to document the long term follow-up results.

\section{Material and Methods}

Medical records of 27 consecutive patients who underwent primary pterygium surgery with conjunctival transposition flap technique between January 2009 and January 2011 were reviewed. Demographic data, pterygium size, surgery time, complications, follow-up time and recurrence rate were evaluated. This study followed the tenets of the Declaration of Helsinki and informed consent was obtained from all of the patients.

Pterygium size was evaluated biomicroscopically. Only nasally located pterygia cases were included in the study. The surgeries were done by the same surgeon (ADB) under local anesthesia. Subconjunctival anesthesia including lidocaine $20 \mathrm{mg} /$ $\mathrm{ml}$ and epinephirine $0.0125 \mathrm{mg} / \mathrm{ml}$ was enjected. The body of the pterygium was cut from the limbus by Wescott's scissors. The head of the pterygium was detached from the cornea and subconjunctival fibrous tissue was removed with crescent blade. Minimum amount of cauterization was applied on the sclera. The flap was created on inferomedial quadrant of the conjunctiva near the margin of the bare sclera (Figure 1). The flap was dissected

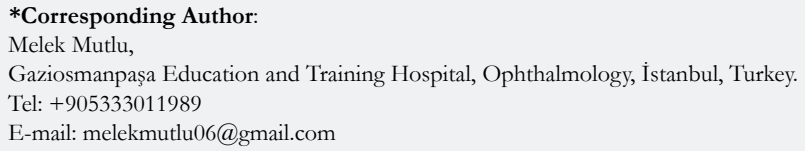

Citation: Melek Mutlu, Ayşe Dolar Bilge. Long - Term Results of Primary Pterygium Surgery with Conjunctival Transposition Flap. Int J Ophthalmol Eye Res. 2020;8(1):421-423. doi: http://dx.doi.org/10.19070/2332-290X-2000085

Copyright: Melek Mutlu을 2020. This is an open-access article distributed under the terms of the Creative Commons Attribution License, which permits unrestricted use, distribution and reproduction in any medium, provided the original author and source are credited. 
from the Tenon's capsule carefully, transposed to the defectted area and separately sutured with 8.0 vicryl sutures to surrounding conjunctiva (Figure 2). Topical dexamethasone and tobramycine combination eye drop were prescribed to the patients 4 times a day for 4 weeks (Figure 3).

\section{Results}

The mean age of the patients was 57 years (39-70 years) and 7 of them were female, 20 of them were male. Mean pterygium size was $2,8 \mathrm{~mm}(2-3,5 \mathrm{~mm})$ and mean surgery time was 15.9 minutes (13-23 minutes). Pateints were controlled 1st day, 1st week, 1st and 6th month and then yearly after the surgery. Conjunctival, corneal and anterior chamber changes were recorded. Mean follow-up time was 72 months (67-82 months).

Early postoperative complications like hematoma, flap edema, dehiscence of flap were not seen any of the patients. Recurrence was defined as the occurrence of fibrovascular regrowth crossing the limbus and extended over the cornea. Only 1 case $(\% 3,7)$ of recurrence was observed in our series during the follow-up. Recurrence of the ptergium was seen postoperative $4^{\text {th }}$ month in the patient.

\section{Discussion}

Pterygium surgery success can be defined as postoperative good cosmesis and ocular surface with no recurrence in time. Recurrences usually occur within 6 months after the surgery [14]. Surgical technique, type of suture, antimetobolite usage, age of patient, enviromental factors, type of pterygium or surgeon skills are possible factors affecting recurrence.

Reccurence rates after pterygium surgery are variable in the literature. Varssano et al., [15] reported 11.4\% (the mean follow-up time 34 months) with conjunctival autograft method. One of the comparative study between limbal sliding graft, primary closure and amniotic membrane grafting reported recurrence rate $7 \%$, $27 \%$ and $56 \%$ respectively (mean follow-up time 12 months)[16]. In our previous study comparing conjunctival autograft and transpositional flap technique done by the same surgeon, recurrence was observed in one case in each group during one yaer follow-up but the operation time was statistically longer in conjuntival autograft group [17]. In this study we showed no change in reccurence rate in conjuntival transposition flap group in long term follow-up (\%3.7).

Figure 1.
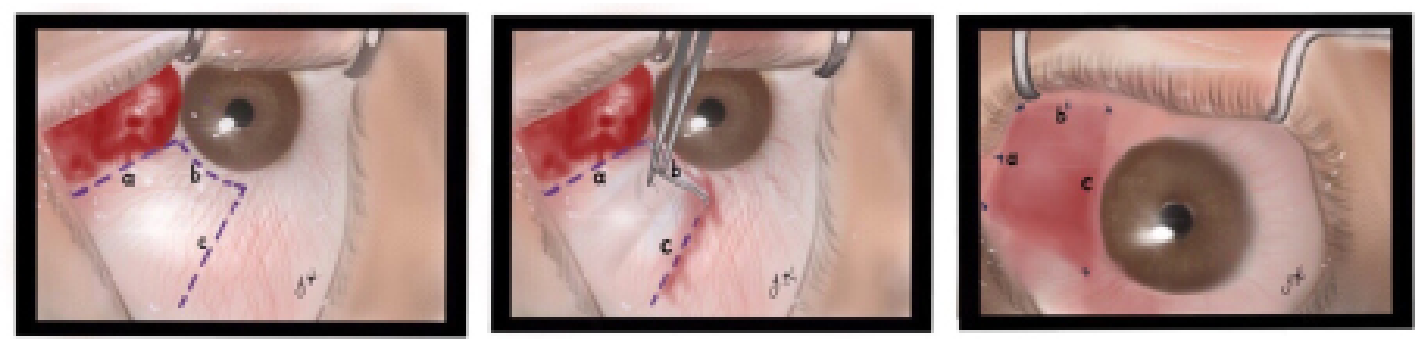

Figure 2.

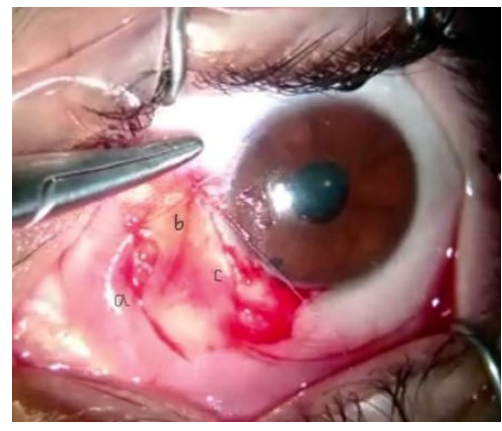

Figure 3.

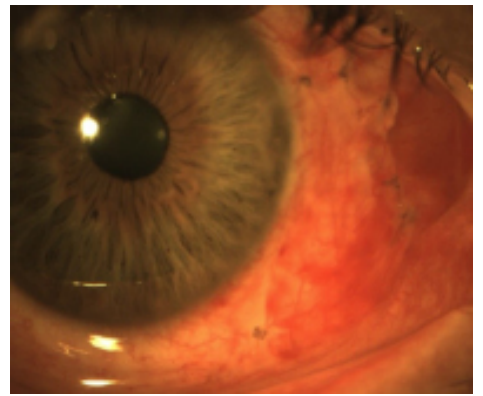


One of the large series with 913 eyes by Lei at al., documented $1.6 \%$ reccurrence rate in one year after conjunctival pedunculated flap method [18]. Kim et al., [19] compared conjunctival rotation flap and conjunctival autograft and they showed that graft or flap edema was significantly higher in autograft group. This can be because of the preservation of vascular integrity higher in conjunctival flap method. But the recurrence rates were similar between the groups.

Preparing the conjunctival autograft takes a long time and orientation of the graft is important in terms of upside-down or limbal side position. Conjunctival scarring in donor site, incomplete coverage of the bare sclera, graft edema, graft loss, graft inversion are some of the disadvantages of autograft technique [20, 21]. Flap related problems such as flap dehiscence, flap edema or flap retraction were not seen our case series. Since taking graft from superior or inferior quadrants cause no diffence in terms of recurrence we obtained the flap from the inferior qudrant for possible filtration surgery in the future.

\section{Conclusion}

Conjuctival transposition flap technique in primary pterygium surgery is very effective and less time consuming method with lower recurrence rates in long term follow-up. Trasferring preserved vascular network by conjuctival flap leads rapid recovery and is another advantage. The technique is also very useful due to lack of graft related problems such as graft loss, orientation difficulties and postoperative graft edema.

\section{Acknowledgement}

The authors would like to extend thanks to medical art/illustrator Dr. Yeşim Kutlutürk for preparing figures.

\section{References}

[1]. Cameron ME. Histology of pterygium:an electronmicroscopic study. Br J Ophthalmol. 1983;67(9):604-608. PMID: 6882718.

[2]. King JJH.The pterygium. Brief review and evaluation of certain methods of treatment. Arch Ophthalmol.1950;44(6): 854-869. PMID: 14777214.

[3]. Mahdy MA, Bahatia J. Treatment of primary pterygium role of limbal stem cells and conjunctival autograft transplantation. Oman Journal of Ophthalmology. 2009;19(5):729-32. PMID: 19787589.

[4]. Eksteen J, Stulting AA, Nel M. Rotational conjunctival flap surgery reduces recurrence of pterygium. SAMJ.2010;100(11):726-727. PMID: 21081024.

[5]. Sekeroglu HT, Erdem E, Dogan NC, Yagmur M, Ersoz R, Dogan A. Sutureless amniotic membrane transplantation combined with narrowstrip conjunctival autograft for pterygium.International Ophthalmology.2011;31(6):433-438.PMID: 22146880.

[6]. Martins TG, Costa AL, Alves MR, Chammas R, Schor P. Mitomycin C in pterygium treatment. Int J Ophthalmol. 2016;9(3):465-468. PMID: 27158622.

[7]. Akarsu C, Taner P, Ergin A. 5-Fluorouracil as chemoadjuvant for primary pterygium surgery: preliminary report. Cornea. 2003;22(6):522-526. PMID: 12883344

[8]. Park J, Son Y, Suh E. Effect of transverse conjunctivaladvancementflap surgery for primary pterygium. Can J Ophthalmol.2016;51(6):401-407. PMID: 27938948

[9]. McCoombes JA, Hirst LW, Isbell GP. Sliding conjunctival flap for the treatment of primary pterygium. Ophthalmology. 1994;101(1):169-173.

[10]. Kim S, Yang Y, Kim J. Primary pterygium surgery using the inferior conjunctival transposition flap. Ophthalmic Surg Lasers. 1998;29(7):608-611. PMID: 9674015.

[11]. Kaya M, Tunc M. Vertical conjunctival bridge flaps in pterygium surgery. Ophthalmic Surg Lasers Imaging. 2003;34(4):279-283. PMID: 12875455.

[12]. Kim M, Chung SH, Lee JH, Lee HK, Seo KY. Comparison of mini-flap technique and conjunctival autograft transplantation without mitomycin $\mathrm{C}$ in primary and recurrent pterygium. Ophthalmologica.2008;222(4):265-271. PMID: 18536527.

[13]. Aslan L, Aslankurt M, Aksoy A, Ozdemir M, Yüksel E. Comparison of wide conjunctivalflap and conjunctival autografting techniques in pterygium surgery. JOphthalmol. 2013;2013:209401. PMID: 23533701.

[14]. Adamis AP, Starck T, Kenyon KR. The management of pterygium. Ophthalmol Clin North Am. 1990;3:611-623.

[15]. Varssano D, Shalev H, Lazar M, Fischer N. Pterygium excision with conjunctival autograft: true survival rate statistics. Cornea. 2013;32(9):12431250. PMID: 23594771.

[16]. Kurna SA, Altun A, Aksu B, Kurna R, Sengor T. Comparing treatment options of pterygium: limbal sliding flap transplantation, primary closing, and amniotic membrane grafting. Eur J Ophthalmol. 2013; 23(4): 480-487. PMID: 23483495.

[17]. Bilge AD. Comparison of conjunctival autograft and conjunctival transposition flap techniques in primary pterygium surgery. Saudi J Ophthalmol. 2018; 32(2): 110-113. PMID: 29942178

[18]. Lei G. Surgery for pterygium using a conjunctival pedunculated flap slide. Br J Ophthalmol. 1996; 80(1): 33-34. PMID: 8664228.

[19]. Kim SH, Oh JH, Do JR, Chuck RS, Park CY. A comparison of anchored conjunctival rotation flap and conjunctival autograft techniques in pterygium surgery. Cornea. 2013; 32(12): 1578-1581. PMID: 24097183.

[20]. Prabhasawat P, Barton K, Burkett G, Tseng SC. Comparison of conjunctival autografts, amniotic membrane grafts, and primary closure for pterygium excision. Ophthalmology. 1997; 104(6): 974-985. PMID: 9186439.

[21]. Alpay A, Ugurbas SH, Erdogan B. Comparing techniques for pterygium surgery. Clin Ophthalmol. 2009; 3: 69-74. PMID: 19668546. 